focus on law schools and the legal profession, analyzing the declining presence of lawyers in Congress.

Chuck is survived by his wife, $\mathrm{Pa}$ tricia Tipton Longley (also a Ph.D. in political science from Chapel Hill), their daughter, Alexa, and a brother, Peter.

His humor, his intense desire to elicit the best from his students, and his dedication to his profession, his department, and his university, will be sorely missed. His recent interest in antiques and rare books brought the occasional fascinating find to our attention. And for those of us trying to apply chaos theory to political science, visits to his office were instructive. Like the upwelling of magma in the mid-oceanic ridge, old McGovern posters might unexpectedly emerge, juxtaposed with large plastic birds of indeterminate species. Chaos was not complete, though: his students were everlastingly grateful that he kept all his letters of recommendation on file with the department secretary.

John Peeler

Bucknell University

\section{Thomas F. Richards}

Thomas F. Richards died on Monday, December 21, 1998, at his home in Haddonfield, New Jersey. Tom received a B.A. from San Francisco State University, masters degrees from UCLA and NYU, and a doctorate in education from Rutgers University. He published many articles and a book. He was a full professor of political science at Brookdale Community College and served as president of the New Jersey Political Science Association. Teaching was his lifelong passion. In his 35 years of teaching, he continually strived to bring the community into the classroom and the classroom into the community. By visiting places prominent in the news, such as Grenada, Nicaragua, Vietnam, Cuba, China, and the Soviet Union, he was able to bridge the gap for his students between academia and the "real world." He taught abroad in several countries, including Canada, Ecuador, and Mexico, and gave lectures throughout the world. He loved to travel and was committed to peace, civil rights, civil liberties, and ethics.

Tom was an active member of APSA's Departmental Services Committee, and served as its chair in 1997 . He was committed to encouraging students to study and major in political science and he encouraged the Association to go forward with its proposal to produce a video on careers and the (undergraduate) study of political science.

Sheilah Mann American Political Science Association 